\title{
AXES OF WORLD POWER IN THE 21ST CENTURY: AN ANALYTICAL PROPOSAL
}

\section{Paulo Fagundes Visentini ${ }^{1}$}

\section{Introduction}

Studies in the areas of International Relations and Defense have as one of its primary objectives the measurement of world power, identifying and classifying hierarchically the Great and Medium Powers. However, the criteria for this are very questionable, since they are based predominantly on quantitative elements arranged according to previously established theories, often (a)historical.

They generally take into account the country's geographical area, its natural wealth (agricultural and mineral), the weight of its economy (in general the Gross Domestic Product and per capita) and the size and structure of its population. Also considered are the geopolitical position, membership in relevant International Organizations (G-7, OECD, OTAN, UNSC), political-institutional stability and, last but not least, the size and quality of the Armed Forces. Usually, these items are quantified and tabulated, producing a ranking of the powers and, based on these references, a series of strategic reflections and geopolitical scenarios are presented (Merle I98I, II9 ; Morgenthau 2003, 215 ; Kennedy I989, 4I7 ; Carr I98I, 99).

Undoubtedly, these are significant components, but the way in which they are articulated and their relative importance are related to other qualitative elements. First, there is the historical evolution (each Nation-State has its specific characteristics), the level of social and economic development, the degree of articulation of the elites in power, the existence of a national project, the international connections and the positioning in the world system, among others (Halliday 2007; Wallerstein 2004, 21; Arrighi 1996, 59; Brucan I974, I40).

I Full Professor of International Relations at UFRGS; Researcher at CNPq; Coordinator of NERINT/UFRGS and Editor of Austral: Brazilian Journal of Strategy and International Relations. paulovi.ufrgs@gmail.com 
A country may possess significant military power and a large economy, but it can find itself in decline due to a change in the world economy and the emergence of challenging power poles. Moreover, although in possession of a strong economy and quantitative military capabilities, sometimes they have sovereignty limitations, which make difficult to convert these elements into an effective instrument of action. Thus, the systematization of the material elements of power can generate an erroneous statistical conception and a misleading strategic appraisal.

In modern and contemporary times, with the emergence and affirmation of the world system, the Absolutist Dynastic States, the players of the Ancien Régime, were formed in Europe. Then the French Revolution introduced the ideological element (radical change vs. conservatism) and national element in International Relations. The Congress of Vienna (I8I5), in turn, introduced the notion of Balance of Power between the Great Powers (Great Britain, France, Russia, Prussia and the Austro-Hungarian Empire) (Kissinger I973). At the same time, nationalism and the Nation State emerged. Later on, as result of the First and Second World Wars, the European powers started to be classified as middle powers (especially when they lost their colonial empires), while the United States and Russia (transformed into the Soviet Union) became superpowers. Some States from the Geopolitical South (the Third World) were also included in the list of middle powers (or regional). But the explanatory paradigms and international reality became fluids with the end of the Cold War.

Therefore, a process that was already complicated in an era of a recognized leadership and hegemony, had become even more complex and uncertain in a phase of transition. In this sense, the aim of this article is to contribute to an understanding of the State's power position in the framework of the post-Cold War International System, particularly in the 2Ist century. It is an exploratory vision, aiming to take into account current actions and possible trends for the immediate future, in the context of the economic crisis since 2008 and the ongoing disarticulation of "globalization" itself.

What should be considered, more than ideological or geopolitical rivalries, is the political-economic position States occupy in the world power structure. In this context, the first group of contemporary international politics make up the Anglo-Saxon military-rentier axis: United States, Canada, United Kingdom, Australia, New Zealand and, tangentially, Israel. These are the hegemonic nations that hold military, diplomatic, financial, technological, intelligence and communications resources. Being in the post-industrial rentier phase, it lives on the resources of the other nations, employing the means mentioned above. 
The second is the the developed industrial axis of the European Union, Japan and the Asian Tigers. With an advanced productive industrial capitalism and a high standard of living, it differs from the first group, because this one lacks the traditional power resources, such as the military, and full state sovereignty. They were protected during the Cold War, but today the situation is uncertain and the tensions with the former are increasing. Further developments will depend on the political attitude to be adopted by relevant nations of the axis, such as Germany and Japan, the defeated of World War II.

The third is the emerging unorthodox industrial axis, integrated by the great nations of the BRICS, especially China and Russia, as well as Turkey and Iran, where the structures of power and participation in the economy are relevant. This is defined as semiperiphery. Like the previous one, its immediate and primary objective is to avoid an armed conflict of global dimensions and to maintain its economic development. With resources to defend themselves, they fail to project power on a planetary scale and depend to some extent on the attitude that will be adopted by the second axis.

Finally, the fourth is the agrarian, mineral and demographic peripheral axis, composed of the middle and small nations of Latin America, Africa, and geographical Asia (which includes the Middle East). They have abundant human, agricultural, or mineral resources (including energy) but do not have military capability or diplomatic articulation, tending to act in a fragmented way and forming a contested zone for other axes. Brazil and South Africa seem to be absorbed by their internal political agendas and risk becoming part of this group.

\section{The Anglo-Saxon military-rentier axis}

The dominant group of world politics is integrated into the Anglo-Saxon military-rentier axis: United States, Canada, United Kingdom, Australia and New Zealand. More than a simple "linguistic community", it represents a continuity of the Maritime Empires and its geopolitics. It is the heir to Igth century British liberal hegemony and its later colonial empire, as well as the alliances (and results) of the two World Wars against the middle powers (Germany and Japan) and the anti-socialist/anti-Soviet Cold War.

These are collectively hegemonic nations, which have military, diplomatic, financial, technological, intelligence and logistical and informational communications resources. Having reached the post-industrial rentier phase (in the last quarter of the twentieth century), they depend on the resources of other nations, employing the means mentioned above. With the current Sci- 
entific-Technological Revolution underway, particular attention must be paid to the last three aspects, which had revolutionized international relations and defense systems.

The so-called UKUSA (United Kingdom and United States of America) agreement, established in the second half of the I940s between Washington and London, gave rise in the I980 to the system known as Echelon, the electronic intelligence and information system. This system, based in England, collects, processes, and shares information among the Five Eye countries: The United States, Canada, the United Kingdom, Australia and New Zealand. Previously focused on military issues against the Warsaw Pact during the Cold War, from the I980s onwards, it included industrial and political espionage, including NATO allies in the European Union, as denounced in the European Parliament in 2000 (Silva 20I8).

The system does not only encompass the metropolitan territory of these countries, but a cluster of small islands and strategic points in all Oceans and continents. One of the points of the Echelon world espionage system, for example, is located on the British island of Ascension in the center of the Atlantic Ocean. These are not only "antennae" of the system, but also military bases and/or Tax Heavens, connected to the financial center of London. The United Kingdom was able to adapt to its hegemonic decline, through an alliance with the United States, with both countries converging on UN Security Council votes.

The United States is the leader of the group, with the dollar, diplomacy, the military, the cultural industry, and the almost exclusive control of the electronic media and International Organizations. But the others are not "dominated", but rather are integral and active (though discrete) parts of the group. Israel, tangentially, is associated with the group, but has its own regional agenda, maintains some independence and is a nuclear power. There are also European appendices from a strategic point of view such as Spain, Portugal, the Netherlands, Denmark, Poland, Hungary, Croatia, Romania, Bulgaria and the Baltic countries (Lithuania, Latvia and Estonia).

Although they are members of the European Union, as well as the UK up until Brexit, their focus in the area of Defense has been the convergence with the Anglo-Saxon axis. In the Geopolitical South (the Third World), Chile, Colombia, Morocco, Kenya and Saudi Arabia (although Riyadh holds some autonomy) can be mentioned as partners of the axis with agendas of "regional allies", projecting influence in their surroundings. But these countries do not have the power requirements previously enumerated to be part of the previous group or the ability to influence decisions and strategies and neither are 
desired as partners by the Big Five².

\section{The developed industrial axis}

The second group is the industrially-developed axis of the European Union, Japan and the Asian Tigers. With an advanced productive industrial capitalism and a high standard of living, it differs from the first, because this group lacks the traditional power resources (except France), like military and full sovereignty. They were protected during the Cold War, but today the situation is uncertain and tensions with the first axis are increasing. Further developments will depend on the political attitude to be adopted by relevant nations of the axis, such as Germany and Japan, the defeated of World War II, and France, which has proved incapable of acting strategically in a coherent way.

Its composition is based on the previous middle powers that became industrialized by late nineteenth century (Central Europe and Japan) and after World War II (the rest of Europe and the Asian Tigers). During the Cold War they were engaged as members of NATO (Europe) or through Bilateral Defense Pacts in East Asia. And in the case of the members of the fascist Axis (Berlin, Rome and Tokyo), there are serious institutional and military limitations to full sovereignty. This is due not just because of American troops and military bases in its territory (some on behalf of NATO), but also from the obstacles to the constitution of their own military and aerospace technology and industry. Also, the fact that these states were rebuilt by occupation forces after I945, which shaped their elites, nowadays divided and lacking strategic vision, poses a significant weight.

The French case is emblematic because, among the countries of this axis, it has an unique position: nuclear power status, permanent membership at the UN Security Council, with a network of bases around the world and an independent aerospace technology and industry. Together with Germany, it represents the hard core of the European Union, but since the I970s it is immersed in a strategic identity crisis. For their turn, in Germany and Japan, with their significant advanced technologies and economies, elites appear to be suffering from a post-Cold War syndrome, failing to define a coherent project for its international action. The case of Germany's relationship with Russia and the United States is an example: with economic interests converging with Moscow and the defense agenda being linked to Washington.

2 In allusion to the five African animals capable of self-defense: the lion, the elephant, the buffalo, the rhinoceros and the leopard. In this case, these are the United States, Canada, the United Kingdom, Australia and New Zealand. 
In East Asia, with Japan, South Korea, and Taiwan, the same is true in relation to United States and China. Artificially fostered military crises sustain a permanent state of insecurity, aiming to limit the convergence between the Tigers and the Chinese Dragon. Provocations towards North Korea, which reacts in the expected and desired manner, proved to be just enough to maintain alignment with Washington's security plans. However, Trump's US and China trade war goes well beyond a renegotiation dispute among partners, since the real economic and technological conflict, which is much more complex and multidimensional is taking place between the US and the EU, in particularly Germany.

In the same logic, it is worth to remember that Samuel Huntington (1997, 195) defined that the West's core was located in the North Atlantic, and NATO is its linkage organization. So, the EU and Japan/Asian Tigers dilemma is that their relations with the US are getting weaker, whereas they grow stronger with the BRICS, in particular China and Russia. Nevertheless, diplomatic-security ties with Washington, as well as the arrangement between the ruling elites of the two shores of the Pacific, remain strong.

Color Revolutions arrived in Europe with Brexit, "populist” political movements and destabilizing radical violence (such as the French Yellow Jackets), as well as an open disrespect for community norms, terrorist attacks, separatism and massive induced migrations are part of the same process. Clearly, there is a sociological basis for such a phenomenon, with the gradual wreck of the Welfare State and the draining out of the universe of traditional politics, but there is a synchronization. Steve Bannon is not a "rebel without a cause."

\section{The semi-peripheral industrially-emergent axis}

The third group consists of the emerging industrial axis, composed of the great BRICS nations, especially China and Russia, as well as Turkey and Iran, in which the state's participation in development is a determining factor. Conceptually defined as the semi-periphery, they are clearly targeted by Donald Trump's US and his America First doctrine. Like the previous axis, its immediate goal is to avoid an armed conflict of global dimensions and to maintain its economic development. With resources to defend themselves, they still cannot project global military power and depend on the attitudes that the second axis will adopt. But some of them have deterrent power and are becoming more assertive as the crisis that began in 2008 and global tensions deepen.

Russia and China are permanent members of the UN Security Coun- 
cil and, like India, nuclear powers. China maintains its socialist regime with a globalized multifaceted development project with high growth rates that have already made the country the second largest economy in the world. And this productive advance is being accompanied by the increase of its technological and defense capabilities. The Chinese State covers $22 \%$ of the world's population and enjoys internal stability and international autonomy. Its "socialist market" development project is similar to the old Soviet New Political Economy (NEP) of the I920s, but with an internationalized dimension. Its commercial, financial and technological connections, both with developed and developing capitalist countries, have transformed world geo-economy, particularly in the peripheral areas.

In its turn, Russia represents another re-emerging power, since it is the heir of the defeated Soviet superpower after severe weakening and decline in the I990s. Technological capacity, the aerospace and armaments industry, as well as defense capabilities, make it the only state with ability to strategically compete with the United States. However, it suffers from some weaknesses, once its governance is still fragile. It does not have a structuring party (as in China or in the Soviet Union era) and society underwent major transformations and fragmentation. Moreover, from a geopolitical point of view, its surroundings (the "near abroad") and international connections present weaknesses, despite the creation of the Eurasian Economic Union (which aggravated the Ukrainian problem).

As for the Indian elephant, economic growth and an increasing international presence are observed, but with a troubling social backwardness of a rapid growing population, which will surpass the Chinese in a few years. The Chinese population is stabilized and aging, while the Russian has aged and quantitatively receded. However, these two countries have vast territories and natural resources, unlike India. Although India's nuclear status had been supported by the United States, the country faces serious security challenges, both external (China and Pakistan) and internal (terrorism, separatism and Maoist Naxalita guerrilla).

Brazil and South Africa (post-apartheid) experienced accelerated development at the beginning of the 2ist century and, alongside India, created the IBSA Trilateral Cooperation Forum in 2003. But in recent years both nations have experienced serious crises of governability and economic stagnation, currently lacking a strategic project. In the same way, the two nations lost their leadership in the field of regional integration. Brazil, in particular, is on the verge of being downgraded to the fourth axis, which will be analyzed below. Two states that achieved economic and political-military advances were Turkey and Iran, acquiring a position and status similar to that of the BRICS. 
But both find themselves in an extremely vulnerable line of geopolitical fracture and present a certain domestic and international fragility.

However, the BRICS, which came to be characterized as power pole in 2009 (in response to the unfolding of the 2008 crisis), had developed considerable economic and diplomatic mechanisms, although they are not a "bloc", but a forum. In addition to integrating IBSA nations, there is another important organization, the Shanghai Cooperation Organization (SCO), which emerged in 1996 with China, Russia, Kazakhstan, Kyrgyzstan and Tajikistan. Subsequently, Uzbekistan, India and Pakistan joined this bloc (as well as other observer states). It has an economic and security focus and articulates an Eurasian pole, which represents a strategic nightmare for the US (Brzezinski, I998). However, Russia and China are allies, ma non tropo, as both have partially different and competing agendas.

The great emerging nations constitute some sort of semi-periphery, in which the previous accumulation of capital places them in a position of global economic projection, generating a situation in which the growing economic weight clashes with the existing world political order. Putin's Russia cannot be seen solely as an energy power (gas, oil and uranium), since this sector internationalized companies mean a growing global presence. In addition, Moscow became, once more, a major exporter of advanced weapons. In its turn, in addition to China's growing economic presence in Africa and Latin America, the country has launched bold Eurasian initiatives such as the New Silk Road and OBOR (One Belt, One Road). They represent the emergence of a pivotal land zone, which brings together the basic elements of classical geopolitics, with new economic elements.

\section{The agrarian, mineral and demographic peripheral axis}

Finally, the fourth axis is the agrarian, mineral and demographic peripheral, composed of the medium and small nations of Latin America, Africa and geographical Asia (which includes the Middle East). They have abundant human, agricultural, or mineral resources (including energy) but do not have military capability or diplomatic articulation, tending to act in a fragmented way and forming a contested zone for the other axes. Brazil and South Africa, members of the BRICS, seem to be being "downgraded" due to their internal political agendas and disputes, and risk becoming part of this group. 


\section{Structural dimensions}

The Geopolitical South (the Third World) encompasses Latin America, Africa, Western, Central and Southern Asia, in which the growth of world population occurs. Not only they represent a significant reserve of young manpower and potential consumer market, but also generates an unoccupied population surplus that generate migratory and refugee conflicts crises. The United States-Mexico border and the Mediterranean Sea have become extremely vulnerable zones to this phenomenon. The arc from Pakistan to Japan (with the exception of the western half of China) houses more than half the world's population. The Middle East and the northern half of Africa are experiencing strong destabilization.

On the other hand, the consumer democracies of the North use enormous volumes of food and raw materials (energy and minerals, among others), which production and reserves are located in the South (Paiva 20II, 32). This phenomenon is further aggravated by the increase in per capita consumption in emerging nations and the urban middle classes from all the Geopolitical South. There are vast spaces for profitable investments (infrastructure, mining, services, agribusiness), within a framework of growing inter-capitalist competition, which opposes, mainly, the old industrial powers and the emergent ones of the semi-periphery. Thus, this part of the planet is the stage of an economic and strategic dispute that is similar to the one that preceded the First World War.

The Geopolitical South concentrates approximately two thirds of the existing States (quite unequal), with an overwhelming majority with great political-social fragility and military and economic weakness. Their international agenda consists simply of maintaining their existence as a nation and the local elites in power. Many Cold War era coalition initiatives, such as the G-77 and the Non-Aligned Movement, which sought to formulate a common agenda and increase the region's political weight at the UN, lost focus with the end of bipolarity. From the I990s onwards, due to the neoliberal cycle of globalization several regional integration initiatives were presented, but they faced structural difficulties at local and global levels. So, although the GDP of many of the nations of the South is growing, sometimes above the world average, political vulnerability, economic instability and social tension are increasing.

Despite material differences and foreign policy alignments, these states have structurally similar position in the world economy. Directly or indirectly, they are subject to the agendas formulated by the North-Atlantic powers and to the actions of powerful states and transnational mega-companies. Nevertheless, in several regions that make up the Geopolitical South some 
pivot states can be identified, with some political and eventually economic relevance.

\section{Regions and pivot states}

In Latin America, after the "Pink Tide" of center-left governments with advances in the social agenda (without a neoliberal rupture), the trend is the reverse (by several means) of most of them. In addition to domestic changes, there is the emptying of integration projects, such as Mercosur, and of Latin American and South American associations, such as CELAC and UNASUR, respectively. Brazil, as analyzed, finds itself in a political and economic situation that is leading it to the position of a giant member of this fourth axis, while Argentina has been in it for quite some time.

In South America, Chile and Colombia maintain a pro-Washington strategic role, the first with its powerful army and bi-oceanic geopolitical position. Nowadays, the second, with a long-term cooperation with the US in counterinsurgency and in the fight against drug trafficking, plays a significant role in the Venezuelan crisis. Mexico, while still subordinate to the United States economy, has a kind of "negative or unwitting activism", since the issues of migration and drug trafficking are taking a center stage. For its turn, Trump's administration biggest interest in the subcontinent is the economic agenda and containment of China's growing presence with its investments, services, commerce and infrastructure construction.

Today, much more than the Ibero-American region, Africa represents a region in fierce geopolitical dispute between former and emerging powers, which includes the strategic spaces of the Indian and South Atlantic Oceans. Added to this, there is terrorism in its northern half, coups d'état, civil wars - as in the Democratic Republic of Congo and South Sudan - and the collapse of states - such as the ones in Libya and Somalia. Morocco continues as a strategic Western ally, with the pending Western Sahara issue and its campaign as a "Trojan Horse" in the South, in favor of the so-called Atlantic Community (linking the North Atlantic to the South Atlantic). Already South Africa is strategically stagnated by the effects of its post-Apartheid transition agreement, no longer being the largest economy in the continent, a position now occupied by the populous Nigeria.

However, the continent has its own dynamics and states that advance economically and politically. In the context of the African continent, Angola, Nigeria and Ethiopia could be considered sorts of regional powers. Ironically, African cooperation agencies have played a growing role in economic cooper- 
ation and conflict resolution. Djibouti, for its part, had become a core center, not only because of its geopolitical position at the entrance to the Red Sea, but also because it shelters bases of countries such as France, the USA and China. Equally, Kenya also is a Western strategic pivot. The Gulf of Guinea, with its oil resources, has also turned into a strategic region. The clash of the United States and France to the growing Chinese presence is the main cleavage of the continent. Instead of a narrative of victimization, one can see that such a situation has given African states a leverage of political and economic autonomy that they had never experienced in 60 years of independence (Visentini 2013).

The Middle East, like Africa, is a region in a fierce strategic dispute for its geopolitical position and energy resources, but in a much more direct and violent way. Even though this is not unprecedent, nowadays it presents a new meaning which is not restricted to regionally restricted conflicts. It became the Great Middle East, with the inclusion of new states of the Caucasus (Georgia, Armenia and Azerbaijan) and former Soviet Union Central Asia and Afghanistan, stage of the new Great Game or Grand Chessboard. Georgia, Azerbaijan, Turkmenistan and conflicted Afghanistan are a pro-NATO corridor separating Russia and its allies from Central Asia also from its other allies Iran, Armenia and Syria.

Turkey has apparently given up its rapprochement with the European Union and got closer to Russia and Iran, which is considered a threat by Israel, Saudi Arabia and the Gulf Petro-monarchies, except for Qatar and Oman. The domestic political cleavages of Yemen (blocked by Riyadh and devastated by the civil war) were contained by Iran and Saudi Arabia. The Saudi Kingdom undergoes an internal struggle within the ruling elite (dozens of factions of rival princes) and constitutes a fundamentalist theocracy and absolutist monarchy that admitted its association with Israel. The country has a significant oil and financial weight and is a mentor and financier of fundamentalist Islamic movements. In addition to the internationalized civil wars of Syria and Yemen, Iraq remains a battleground, with the Kurdish issue occupying a central position.

However, it would be wrong to think that this is a clash between Sunnis and the West against Shiites. At stake is the attempt by conservative monarchies and Western powers to overthrow secular and modernizing regimes, which include Syria, Yemen, Egypt, Iran (which is modernizing), and Turkey, which has cooled its relationship with NATO and got closer to Russia. The formally "counter-terrorist" intervention in Iraq and Afghanistan was a failure and the attempt to overthrow the Ba'as regime in Syria, was also unsuccessful, making room for Russia in the region.

In South Asia, added to India (already analyzed), Pakistan (a nuclear 
power) has approached China and Iran. It is worth mentioning the prominence and relative autonomy of the Association of Southeast Asian Nations (ASEAN) Io member states. Made of rich (Singapore and Malaysia) and poor sates (Philippines), monarchies and republics, large and small, socialist and capitalist, stable and unstable and democratic regimes Western-like (Thailand) and considered authoritarian (Myanmar), ASEAN manages to develop a common autonomous political agenda. The Association represents a balance between the giants China and India, despite tensions in the South China Sea. On the Korean peninsula (along with Japan), local tensions are framed by global antagonisms.

The huge Pacific Ocean space is under the sea powers control, with Australia (called in the region "USA of Pacific") and New Zealand playing an important role, controlling numerous archipelagos, as well as the United States, France and UK. The Indian Ocean is, in turn, a disputed space, with the last three nations (plus Australia) occupying a dominant position, but having to face the growing Chinese and Russian naval presence. On the other hand, the strategic spots of the South Atlantic are at is center, in sea corridors to other Oceans, which are quietly controlled by the United Kingdom. Finally, even the Arctic and Antarctic polar spaces became regions where the economic and military presence of the developed capitalist powers rivals with the emerging ones.

\section{Structures, processes and trends}

The end of the Cold War and its bipolar system produced new realities and theoretical challenges. Many attempts to interpret it have been sought, although it seems clear that the US and the Anglo-Saxon powers that are part of the first axis of power remain dominant, but in a framework of accelerated mutation and leaning towards multipolarity. Just as Kissinger (I973) very well defined in his doctoral thesis regarding the European balance of power, there is a Global Balance of Power (unstable) at the beginning of the $2 \mathrm{I}^{\text {st }}$ century. There are two levels of international cleavages, which are not overlapping exactly: one political and the other economic, which may indicate an asynchrony between the structure of political power and the one of economic power.

Political cleavages that affect the distribution of world power oppose China and Russia (or the hard core of the BRICS) on one side and the Anglo-Saxon powers on the other, with the European Union/Japan group as reluctant allies. In its turn, economic cleavages go well beyond the "emerging vs. declining" view, as the Trump administration is showing. It is true that 
Asia had become the great industrial manufacturing center of the world, but the international economy is characterized by a dynamic that is, at the same time, of integration and conflict (as of an uneven and combined development). As Arrighi (1996) pinpointed, the world system is characterized by the coexistence between territorial states and capital, with transnational mobility.

Therefore, while on the one hand emerging countries, as national states, demand a share of power compatible with their increasing economic weight, on the other they are linked to large developed or post-industrial nations. In this context, the US-China "Trade War" resembles the US-Japan one of the I980s. China has a symbiotic relationship with the United States, and the current dispute seems to contain elements of renegotiation of the economic "pact" between them. The real target of American attack is Europe centered around Germany (its advanced capitalist rival) and the new containment of semi-peripheral states of the region that it geopolitically controls (as in Brazil's case).

It does not mean, however, that the American/Anglo-Saxon power will maintain its dominant position. Historian and demographer Emmanuel Todd $(2003,4)$ argued that

"there will be no American empire. The world is too vast, diverse and dynamic to accept the dominance of a single power. The examination of the demographic and cultural, industrial and monetary, ideological and military forces that transform the planet does not confirm the current vision of an invulnerable America. (...) A realistic picture [shows] a great nation whose power was incontestable, but that the relative decline seems irreversible. The United States was indispensable to the balance of the world; today they cannot maintain their standard of living without the world's subsidies. America, by its military theater activism, directed against insignificant states, tries to mask its ebb. The fight against terrorism, Iraq and the 'axis of evil' are no more than excuses. Because it no longer has the strength to control the larger actors that are Europe and Russia, Japan and China, America will lose this last match for world domination. She will become a great power among others."

The trends brought up by the postmodern and neoliberal world hit the countries differently. The Anglo-Saxon axis has a post-industrial (finance, technology, services) economy that is more administrative (budget balancing), while the developed axis and the emerging axis are productive (commodity producers). In the South, the weakening of the state, the surplus population and insufficient development provoke increasing crime and migration, but not of the poorer. 
In addition, social consequences alter the structure of society. While in the North the cities are degraded (Detroit is the most radical case), in the South arise chaotic megalopolis, with crime and pollution. Drug use on a growing scale, in addition to profitable business, represents a form of social control of the youth, which seeks niches and does not engage in politics in both the North and the South. Outsourcing and fragmented app jobs, as well as the "entrepreneur" of the "creative economy" replace the old syndicated working class.

How does this stage of capitalism affect international relations and the hierarchy between powers? Immigration transforms the North from within, just as it did with the Roman Empire, but differently. In postcolonial states (historically recipients of immigrants) there is some assimilation, while in Europe there are growing tensions in an aging society with no new political projects. In the South, a producer of commodities, the attitude of the elites is different, lacking a project and in a hasty economic downturn, with Latin America being the worst case. Due to the Technological Revolution and the progress of other regions, an irrecoverable gap is being formed.

In Africa and the post-Arab Spring Middle East, there seems to be a reshaping of the ruling elites, with the signaling of new national projects and changes in international alliances. As Todd (2003) shows in his work, the Arab and Islamic world is in the process of demographic and political modernization. In Asia, especially in the eastern portion, nowadays there are more committed projects and elites, despite systemic contradictions. Curiously, little is being said about the fact that, for decades, the country with the best economic performance has been the People's Republic of China, a socialist state.

The shaping of a larger interconnected Eurasian space (which links the Middle East by land) seems to be the greatest fear of US strategists and their allies. As America loses its utility to other nations, for how long will "counter-terrorism" be an effective means of action? Nothing seems to lead to an update of the United Nations structure, venturesome leaders rise and tensions build up, in the void of defined strategies. Therefore, more than ever, it is necessary to think over the ongoing changes and their impact in the great powers game. 


\section{ANNEX}

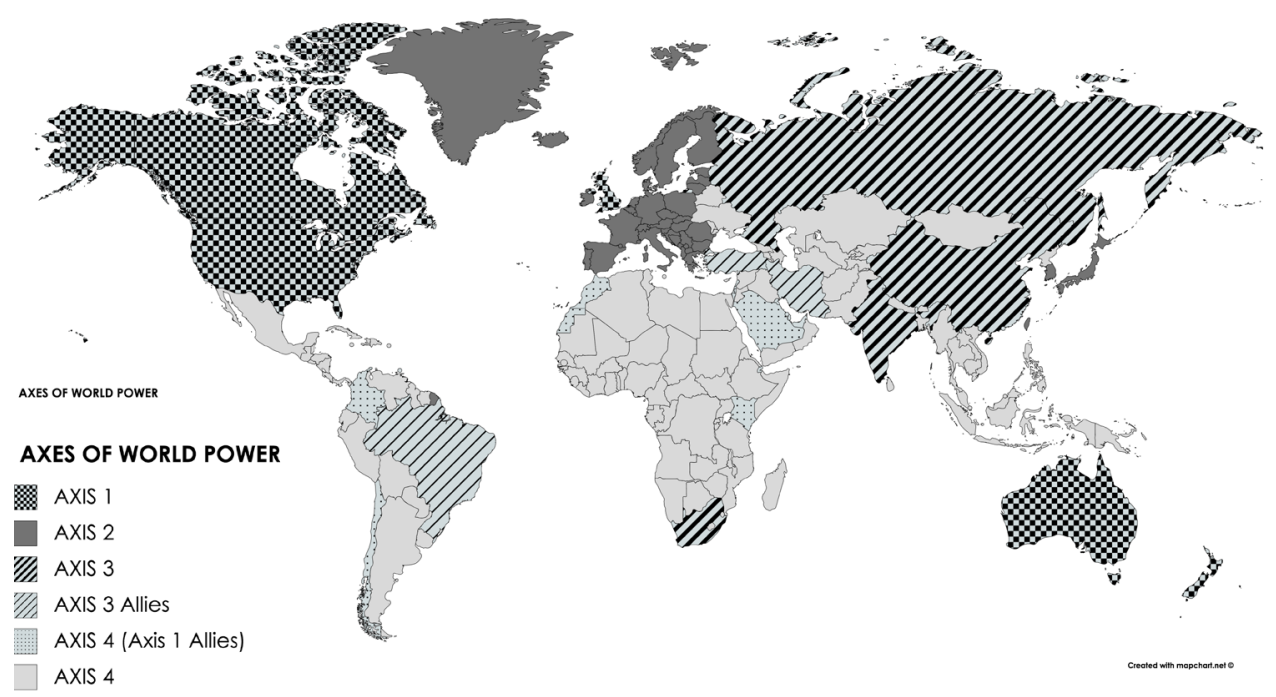

\section{REFERENCES}

Arrighi, Giovanni. I996. O longo século XX: Dinheiro, poder e as origens do nosso tempo. Rio de Janeiro/São Paulo: Contraponto/Unesp.

Brucan, Silviu. I974. La disolución del poder mundial. Sociologia de las relaciones internacionales y política. Mexico: Siglo XXI.

Brezezinski, Zbigniew. I998. El Gran Tablero Mundial. La supremacia estadounidense $y$ sus imperativos geoestratégicos. Barcelona: Paidós.

Carr, Edward. 1981. Vinte anos de crise: 1919-1939. Brasília: Ed. UnB.

Halliday, Fred. 2007. Repensando as Relações Internacionais. Porto Alegre: Ed. Da UFRGS.

Huntington, Samuel. I997. O choque de Civilizações e a recomposição da ordem mundial. Rio de Janeiro: Objetiva.

Kennedy, Paul. I989. Ascensão e queda das grandes potências: Transformação econômica e conflito militar de 1500 a 2000. Rio de Janeiro: Campus.

Kissinger, Henry. I973. O mundo restaurado. Rio de Janeiro: José Olympio.

Merle, Marcel. I98I. Sociologia das Relações Internacionais. Brasília: Ed. Universidade de Brasília.

Morgenthau, Hans. 2003. A política entre as nações. Brasília: Ed. Da UnB. 
Paiva, Luiz Eduardo Rocha. 20Iı. "Principais áreas de fricção no mundo atual: reflexos para a defesa nacional". In: Acioly, Luciana; Moraes, Rodrigo de (Orgs). 20II. Prospectiva, estratégias e cenários globais. Brasília: IPEA.

Silva, Antonio Ruy de Almeida. 20I8. A Diplomacia de Defesa na Política Internacional. Porto Alegre: Palmarinca/ Rio de Janeiro: ESG.

Todd, Emmanuel. 20I3. Depois do Império: a decomposição do sistema americano. Rio de Janeiro: Record.

Visentini, Paulo. 20I3. A África e as potências emergentes. Porto Alegre: Leitura XXI/Cebrafrica-UFRGS.

Wallerstein, Immanuel. 2004. O declínio do poder americano. Rio de Janeiro: Contraponto.

\begin{abstract}
The ranking of the hierarchy and grouping of World Powers is not based exclusively on material indicators such as economics, natural resources, territorial extension, population size and military resources. It is necessary to consider the stage in which the transformational process of the post-Cold War International System is, the position in which a power stands, and general and specific historical trends. The present article proposes a classification that identifies the existence of four axes of world power: I) the Anglo-Saxon military-rentier; 2) the semi-sovereign industriallydeveloped; 3) the semi-peripheral industrially-emergent; and 4) the agrarian, mineral and demographic peripheral.
\end{abstract}

\title{
KEYWORDS
}

World Powers; Axes of Power; International System

Received on April 10, 2019

Approved on April 11, 2019

Translated by Maria Gabriela Vieira 